\title{
Codings of Blackness in Mexican Cinema: An Analysis of La Negrada
}

\author{
Ebony Marie Bailey • Universidad Nacional Autónoma de México
}

\begin{abstract}
In a country whose national identity revolves around the idea of mestizaje, Blackness has been omitted from official discourses surrounding mexicanidad. As a result, Afro populations in Mexico have been subjected to codings that render them invisible, otherized and inferior. This paper analyzes the codings of Blackness in Mexico as reflected in the space of art and cinema, specifically the film La Negrada, the first feature fiction film to introduce an all Afro-Mexican cast. On one hand, there is an attempt to reclaim and make visible Mexico's African roots. On the other, the film also walks the line of reproducing a colonial vision of Blackness in Mexico that has existed throughout history. I apply Joaquin Barriendos' concept of “coloniality of seeing” to analyze historical representations of Blackness in Mexican cinema, and to analyze La Negrada in relation to those films.
\end{abstract}

$\mathrm{L}$ a Costa Chica of Oaxaca and Guerrero is a region in Mexico with the country's largest concentration of African-descendants. The first time I traveled there, I did so in an act of soul-searching. As a Blaxican woman born in the United States, I wanted to visit the place that represented the ultimate affirmation of my identity. As a filmmaker, I had hoped that my visit would give me some inspiration for a new project on Afro-Mexican identity.

During that visit, a woman in the mercado asked me what I was doing in La Costa Chica. I told her I was looking for ideas for a new documentary. She replied in a tired, "Otro documental?" Clearly, I was not the first one who would embark on this mission to document this woman's home. Her comment caused me to reflect on my place there. I thought about the colonial implications of documentary filmmaking. Though I did feel a shared identity with this community, I was still from the United States, an outsider. What were my intentions for filming this community? How would I represent this community differently from the documentarians and ethnographers before me?

In cinema, Blackness in Mexico has been represented as an exotic spectacle. In the mid-2oth century, Mexican films that addressed Blackness painted Black people as foreign and problematic, using techniques such as blackface and the "tragic mulatto" narrative. The contemporary film $\mathrm{La}$ Negrada, filmed in La Costa Chica with an all Afro-Mexican cast, attempts to counter this. As a fiction film with the intentions of a documentary, it positions itself as a champion for Afro-Mexican visibility. However, this aspiration for visibility does not absolve the film from representing Blackness through a colonial gaze.

\section{Coloniality of Seeing, el mestizaje and the Erasure of Blackness}

\section{Defining Coloniality}

Coloniality is a residual legacy of colonialism, referring to the "modos de conocer, de producir conocimiento, de producir perspectivas, imágenes y sistemas de imágenes, símbolos [y] medios de significación” (Quijano 12). Quijano describes coloniality as a consequence of colonialism, "el modo más general de dominación en el mundo actual" (14). Coloniality can be considered a "technology of power" in the foucauldian sense, a device that functions in modes of power and knowledge. As Santiago Castro points out, "la colonialidad de poder debe ser vista como una tecnología de racialización de los cuerpos" (91). "Race" is not a biological category of humanity; rather, it is a tool that functions as a "technology" to hierarchize human bodies according to the tone of their skin. This hierarchy is what Walter Mignolo and Pedro Pablo Gómez call "la herida colonial" and it influences 
"los sentidos, las emociones, el intelecto" (6). Furthermore, colonality in history has worked to take away the determination of colonized populations. In discussing the case of Africa, Quijano states that European colonization stripped away the "reconocimiento en el orden cultural mundial dominado por los patrones europeos. Fueron encerrados en la categoría de "exóticos" (13). This "exotic" category has been brought upon Africans and the diaspora throughout history. Mignolo and Gómez elaborate on coloniality's effects on colonized populations:

Se quiere decir que los europeos tienen la confianza de afirmarse en sus propios valores, mientras que en América del Sur, Central y el Caribe (como en otras regiones del mundo no-europeo), se suele no tener las agallas para afirmarse en sus (o en nuestras) propias tradiciones, y estar más seguros si nos apoyamos (como si camináramos con bastón) en algún nombre europeo (y actualmente en algunos nombres, bien sean norteamericanos o que laboran en Norteamérica), que nos asegure que pisamos terreno firme. (Mignolo and Gómez 10)

In essence, coloniality is a series of modes of thinking, knowing, representing and seeing that operates under a structure of power that maintains the hierarchy of racial difference. In the realm of cinema, we can observe how coloniality works through modes of seeing and representing that interact with our knowledge and thoughts on racialized people.

\section{Coloniality of Seeing}

Coloniality of seeing is a concept developed by Joaquín Barriendos that builds upon Quijano's concept of coloniality and expands it into the realm of visuality. The author describes coloniality of seeing as "los procesos de inferiorización racial y epistémica que han caracterizado a los diferentes regímenes visuales de la modernidad/colonialidad" (Barriendos 14). It refers to the visual structures of racial oppression, objectification and exotification - the invisible images and gazes that occupy our everyday spaces. In Latin America, an historic example of coloniality of seeing are the casta paintings, images from the 17 th and 18 th centuries that categorized bodies according to their "races." These illustrations ranged from "pure-blood" Spanish to "half-blood" mulatos (Black with Spanish) and mestizos (Spanish with Indigenous), among many other categories. The paintings operated to execute and preserve racial barriers in the colonial era and also illustrated how the contamination of Black blood lowered one's status in the racial heirarchy.'

Barriendos mentions that in the colonial era, the colonial gaze helped to cultivate the racialized visions of the transatlantic slave trade and economic exploitation of Indigenous people (18). In the twentieth century, cinema has become a structure under which the coloniality of seeing operates. Through ethnographic cinema, this colonial gaze materializes itself through a series of manipulated images and sounds. Fatimah Tobing Rony writes about the role of cinema as an institutional structure that shapes our perceptions of racialized populations. "Cinema has been a primary means through which race and gender are visualized as natural categories" (9). Many early films that are praised for their cinemagraphic innovation - such as Nanook of the North and Birth of a Nation - have worked to inferiorize and otherize racialized populations. In Mexico, the Afro-Mexican communities documented in La Costa Chica are constantly subject to this colonial gaze. The country's colorblind notion of racial harmony, el mestizaje, has had an impact on the way Black and Indigenous populations are represented.

\section{Coloniality in the Mexican Context}

Coloniality in Mexico is rendered through mestizaje - a national ideology that inferiorizes and invisibilizes human bodies according to the color of their skin. Mestizaje describes the majority of "mixed" Mexicans, thus becoming a national identity for Mexico and a fundamental pillar of mexicanidad. In the colonial era, "mestizo" belonged to the casta category that described one as Indigenous and Spanish. One hundred years later, after the Mexican Revolution, the term "mestizo" was readapted to form this ideology of mestizaje, highlighted in La Raza Cósmica by author and educator José Vasconcelos. His text points out the "mixing" of the different racial categories in the "New World." Under this thesis, it is the destiny of Latin America to achieve this "ethnic mission" that will carry society towards modernity (Vasconcelos 10):

Su predestinación, obedece al designio de constituir la cuna de una raza quinta en la que se fundirán todos los pueblos, para reemplazar a las cuatro que aisladamente han venido forjando la Historia. En el suelo de América hallará término la dispersión, allí se consumará la unidad por el triunfo del amor fecundo, y la superación de todas las estirpes. (Vasconcelos 15)

This vasconcilian idea of mestizaje is representative of colonality because it attempts to paint the concept of mestizo as a colorblind racial fusion. However, mestizaje was still founded on modes of knowing, seeing and representing that privileges whiteness, inferiorizes Indigeneity and silences Blackness. It does this in a few ways: first, in his discussion and use of terms like "fusion," "ethnic mission" and even "cosmic," Vasconcelos romanticizes the history of sexual violence in Latin America, choosing instead to focus on these notions of racial fusion and ethnic harmony. Yet, this fusion is not equal, as Vasconcelos implies in his text that whiteness has the most value in this creation of a cosmic race. He describes the white man as having a "clear mind" and makes declarations such as "quizás entre todos 
los caracteres de la quinta raza predominan los caracteres del blanco" and "aceptamos los ideales superiores del blanco" (Vasconcelos 23). In various parts of the text, the author glorifies the triumphs of the white man, such as his capacity to transform nature into industrialization or his contributions to science. And while Vasconcelos gives more value to whiteness, he rarely mentions Blackness in his text. When he does, it is in such a way that essentializes and makes Blackness exotic. For example, when discussing the role of Blackness in the cosmic mission, he describes Black people as "ávido de dicha sensual, ebrio de danzas y desenfrenadas lujurias" (Vasconcelos 19). What we understand as mestizaje today is a strategy of white supremacy: the Vasconcilian narrative of mestizaje continues with racial and colonial hierarchies, while at the same time operating under the myth of colorblindness. Under this myth, Afro-Mexicans are erased and displaced.

This adopted "mestizo" identity at the time extended itself into the arts, including cinema. In the mid 2oth century, the film industry in Mexico boomed as a consequence of the lack of North American films due to World War II. This period was marked as the Golden Age of Mexican cinema ${ }^{2}$. Films from this era often took on nationalistic themes. Genres ranged from comedies, dramas, and musicals, with Rumbera films being quite popular. I will focus on films that dealt with Blackness during the end of the Golden Age and the years that followed it.

\section{Representations of Blackness in the Golden Age}

Representations of Blackness in Mexican cinema have been few and far between - movies from the Golden Age that were about race often linked Blackness in Mexico with foreigners, primarily from the Caribbean. As Roberto Ortiz points out, Black actors often acted in music pieces such as urban and tropical cabarets. "There is a racial division of labor in these musical numbers - the dancing bodies of lightskinned women who photograph white are usually at the forefront, privileged by the camera" (Ortiz 7). When Black characters had protagonistic roles, they were usually stereotypes. We see the Mammy trope portrayed in Angelitos Negros, El Derecho de Nacer, and other movies. Despite the presence of some Black actors in this film, we still see an excessive use of blackface. We see actors in blackface in "anti-racist" films such as Angelitos Negros (1948) and Negro es mi color (1951). It can be argued that the use of blackface in these films is harmless because Mexico does not have the same history of racism as the United States, but Latin America has its own history of racial parody. What role does racial parody play in films that are supposedly anti-racist?

Blackface became known primarily through the minstrel shows in the United States at the beginning of the 19th century, but its tradition in Latin America also has a long and nuanced history. Nineteenth-century Cuba saw the birth of the teatros bufos, a genre of comedy that often mocked
Black people in Cuba through the use of blackface. Francisco Covarrubias was considered the "father" of teatro bufo and debuted the first character in blackface in 1812 as part of a stage play, thirty years before the first formal U.S. minstrel show (Moore 29). The caricatures of blackface in teatro bufo took many different forms, but some popular figures are el negro bozal and el negro categrático. El negro bozal was a recently arrived African who was made fun of for his primitiveness and broken Spanish. El negro caterático was the "upper class" Black man who was ridiculed for living his life as white. "The catedrático represented an aspiring social climber who nevertheless fell short of integration into white society" (Moore 36). In Colombia, we see another manifestation of racial parody through La Negrita Puloy, a burlesque figure who is associated with both objective sexuality and white servitude. At the Carnaval de Barranquilla, women paint themselves darker and dress in red polka dots to become $L a$ Negrita Puloy, who is now a feminine symbol of the carnival. She is folklorized as a source of Afro pride under this myth of racial harmony; meanwhile, racial inequality in Colombia thrives, as Afro-Colombians and Indigenous people are among the most socio-economically marginalized groups in the country.

Danielle M. Roper calls the use of blackface in North America, South America, and the Caribbean "hemispheric blackface," as each region shares traditions of racial parody. Her theory decenters U.S. blackface and suggests that regional parodies of blackface "belong to global economies of representation" (Roper 1). Roper points out that hemispheric blackface in Latin America depends on the colorblind discourse of racial harmony (e.g. el mestizaje) to justify its parodies. "Hemispheric blackface is a form of regional parody that fuses aspects of blackface from the minstrel shows of the US with traditions of racial parody in Latin America" (Roper 6). Roper calls this form of racial parody "hemispheric" to imply that racial impersonation in Latin America and the Carribean belong to larger iconographies of global representation, and are not unique or specific to any individual nation-state (Roper 6).

To illustrate the concept of hemispheric blackface in her dissertation, Roper uses the example of Memin Pinguín, a popular Afro-Mexican comic book character (1). In 2005, Memín received protest in the United States after postage stamps came out in its image. The Mexican population responded with defense, declaring Memín as a symbol of national pride. I attribute this defense from the Mexican public to the colorblind discourse of mestizaje. Mexican author Carlos Monsiváis wrote in El Universal that the U.S. reaction to Memín was due to "la gana de transferir el racismo propio a la sociedad ajena" (par. 17). While he is right in the sense that each country has its own context in the codification and construction of racialized bodies, it is also valid to consider that Memín is an importation of those racist imaginaries and codifications of Blackness from 
around the hemisphere. Marco Polo Hernández Cuevas elaborates on this, stating that Memín Pinguín reproduces U.S. stereotypes of the Sambo ${ }^{3}$ and the Mammy:

La imagen del negro en Memín Pinguín deshumaniza al negro mexicano y lo despoja de su historia. Al igual que las violentas imágenes del "picaninny" o Sambo intentan minimizar el sufrimiento del negro en los Estados Unidos de América, Memín trivializa la experiencia del negro en México. La caricatura de Memín (un Sambo o picaninny) y la de su madre Eufrosina (una Mammy) son réplicas de personajes estadounidenses de la época de Jim Crow. (55)

Memín exemplifies hemispheric blackface by continuing the traditions of racial parody in Latin America, influenced by other racial representations on this side of the world. His image is actually inspired by Afro-Cuban children that creator Yolanda Vargas Dulché saw during her travels. Even if the blackface of Memín didn't have harmful intentions, it nevertheless codifies a certain image of Black people and contributes to the inferiorization of Black bodies.

Like in Memín, the use of Blackface in Angelitos negros and Negro es mi color also represents an importation of codifications and stereotypes of Blackness. Afro-Cuban actress Rita Montaner, who stars in both films, is quite literally portrayed as the Mammy in Angelitos negros - she is an older, dark-skinned and overweight woman who lives to care for a white family. In Negro es mi Color, the actress is not quite a Mammy, but her darkened skin is associated with stereotypical codifications of Blackness -- poverty, ugliness, etc. In "Performing Blackness in Mexican Cinema," Roberto Ortiz points out a contrast in Montaner's roles as "tragic" Black women in these two films versus her musical performances in other Mexican films, such as Ritmos del Caribe. When cast as a poor woman, her skin is darkened, but when playing a singer or dancer, her skin is left in its natural, light state. In this case, blackface is used as a tool to associate Blackness and darkening with undesirability, poverty, and ugliness.

Angelitos negros is perhaps the most known Mexican film of its time that addresses themes of Blackness. All of the "Black" characters featured in the film are actually in blackface, with the exception of Chimmy Monterrey, who plays the best friend of protagonist José Carlos. He is a character capable of enduring open discrimination, without complaint. On one occasion, José Carlos, played by Pedro Infante, dresses up in Blackface in a peculiar act of solidarity, but in doing so, he instrumentalizes it as a tool for exotic fetishism. While performing in Blackface with his ensemble of dancers (who are also in Blackface), it is hard not to think of the U.S. minstrel shows of the 19th century. The presence of Blackface is so abundant that it contradicts the anti-racist message this film is trying to convey. As Theresa Delgadillo points out, "the role of blackace in this film is the reverse in its function...blackface represents the desire to absorb blackness into the Latin American ideal of the mestizaje" (415). The blackface used in this film continues a tired narrative in Latin America that invisibilizes and silences Blackness. Blackness is reduced to a performance for the enjoyment of white and mestizo audiences. In analyzing the presence of blackface in Angelitos negros, B. Christine Arce calls upon Saidiya Hartman's theorization of the role of melodrama and minstrelsy for white audiences in the United States. Arce says that blackface "abstracts the very material nature of blackness," separating the body from the person and the "person from the reality of the social conditions that surround them" (209). Arce also notes:

Blackface becomes a "vehicle" for white self-exploration; it stops being about black people at all, and is more about creating a space for white self-reflection...In his minstrelsy, José Carlos performs the very commodification of blackness that the film is trying to critique, but in this case, instead of providing a safe haven for white reflection, it transforms it into an ironic place for mestizo reflection. (209)

Often times, the narratives of these racial "tragedy" films often paint Blackness as just that, a tragedy. They usually involve a mixed heritage character who has overtly racist views towards Black people throughout the movie, but comes around to being sympathetic at the end. Mixed heritage becomes a plotline. Hernández Cuevas and Richard Jackson point out that this is the "tragic mulatto" stereotype; the "mulatto" character faces an issue for not fitting completely into the "white world" (81). This is specifically the case for Luna in Negro es mi color - she is a light-skinned woman with a Black mother, ungrateful for her African heritage and with a steady desire to enter the white world. While Luna has known all her life of her mixed heritage, in other movies such as Angelitos negros or Dios sabrá juzgarnos, the tragic mulatto character has their heritage revealed to them. Ana Luisa in Angelitos negros despises everything Black - she won't even accept her Black daughter - and is unaware of her mixed heritage for most of the movie. She doesn't develop sympathy towards Black people until her Black caregiver, Mercé, finally reveals to her on her deathbed that she is in fact Ana Luisa's mother. In Dios sabrá juzgarnos, Thomás is revealed to have a Black father as part of a tactic to break him up from his girlfriend. When the reveal happens, it provokes histeria and tears, once again demonstrating Blackness as an obstacle. Although Thomás does not represent the tragic mulatto in the traditional sense that he does not openly disdain Black people, his reveal proves to ruin lives and the ending of the movie becomes a "tragedy," provoked by this obstacle in his and Beatriz's relationship.

It is also interesting to note the way Blackness is treated in the dialogue of these films. Luna's mom says to her in 
Negro es mi color, "llevas a las venas sangre mezclada y puede volver atrás" - reminiscent of the "Salta pa' Tras" casta from the colonial era. In Dios sabrá juzgarnos, Thomas's father tells him, "los negros manchamos hasta nuestros propios hijos.” In Angelitos negros (1948), Mercé hardly challenges Ana-Luisa's treatment of her, although she raised her. On the contrary, Mercé seems highly troubled throughout the movie by this secret burden she has left with Ana Luisa, even crying when she sees that Ana Luisa's baby is Black. There is a lack of agency in the Black characters of these films -- they internalize the shame that the tragic mulatto characters (and society in general) have imposed upon them. Their lives revolve around whiteness.

So even if these movies tried to give "anti-racist" messages, coloniality still worked to portray subordinate images of Black people: the Mammy, the burden, the "tragedy." Blackface is used to characterize and reinforce this imaginary of Black people, and the dialogues among the characters take away the agency of the Black characters.

\section{The Coloniality of Ethnographic Film: La Negrada}

This history of Black representations in Mexican cinema leads us to reflect on a more contemporary piece: La Negrada de Jorge Pérez Solano. Filmed in La Costa Chica de Guerrero y Oaxaca, La Negrada is the first feature-length fiction film with an all Afro-Mexican cast of local, non-professional actors. Its Black actors are not foreigners like in many films of the mid 2oth century. There is no use of Blackface and no narrative involving the "tragic mulatto." In this sense, the film can be seen as a milestone, as it does not depend on tired tropes to construct a narrative about Blackness in Mexico. However, the absence of these tropes does not relieve the film of veering into coloniality. The coloniality in La Negrada is reflected in the way the film treats the AfroMexican population as an ethnographic study. The film itself is based on Cuijla: esbozo etnográfico de un pueblo negro by Gonzalo Aguirre Beltrán, an ethnographic account written in 1958 of the Afro-Mexican population. Aguirre Beltrán was a Mexican anthropologist whose work is some of the earliest anthropological accounts on the African presence in Mexico. Although lauded for bringing visibility to Afro-Mexicans, Beltrán also works in attempt to place Blackness in Mexico under the myth of mestizaje. In his text, La población negra de México. Estudio etnohistórico, he writes:

Extraño constatar que en todos los casos en que se habla de mestizaje en México, sus autores hacen exclusiva referencia a la mezcla de la población dominante con la americana vencida. Nadie se cuida de considerar la parte que toca a los negros en la integración de una cultura en México (Aguirre Beltrán 9).

He critiques mestizaje for its exclusion of Black people, but does not interrogate the concept as a representation of racial hierarchy. In fact, he seems to defend mestizaje in his text, calling it "la base biológica de la nacionalidad mexicana" (153). In calling for the integration of Blackness in Mexico, he does so in hopes of absorbing Blackness within this realm of cosmic mixing that is mestizaje. Under this ethnography, Blackness is not its own entity - it is a sector that is blurred within this imaginary of racial harmony. But even within this "harmony," Blackness holds a position of inferiority in the color spectrum. As Richard L. Jackson points out, "racial blending does not necessarily mean an absence of racial prejudice" (4). He adds that within mestizaje, those who possess more African features will be subject to more descrimination and aesthetic prejudice (Jackson 6).

Indeed, La Negrada manifests itself as a visual representation of these early ethnographic efforts of AfroMexican visibility. In characterizing La Negrada as an ethnographic film, I employ Fatimah Tobing Rony's understanding of the term. She describes ethnographic cinema as a matrix of films that racializes Indigenous peoples and situates them in a "displaced temporal realm" (Rony 8). La Negrada is a visual callback to earlier anthropological projects on AfroMexicans - a desire to absorb Blackness into the mestizaje project rather than represent them as a pueblo with its own self-determination.

The coloniality of the director's intentions with this film is evidenced in his comments about Afro-Mexicans in an interview in the Mexican newspaper, La Jornada:

El tono de piel que utilizo en la película no llega a lo totalmente negro que yo hubiera querido. Me dijeron que si me metía más iba a encontrar más negros, pero son más salvajes. Igual lo hago la próxima vez, allá se les llama azules o rojos, porque a cierta hora del día parece que desprenden un haz con esos tonos; bien bonito. Pero, o eran muy tímidos o muy salvajes, o no querían ni que me les acercara o me decían que les daba pena. (Pérez Solano)

In referring to Black Mexicans as "savage," the director mimics the rhetoric of early anthropological studies on racialized populations. Under this perspective, Black Mexicans are "savages" that need to be civilized under the project of mestizaje. He speaks about Blackness as a prop, a device to be used to advance his narrative. In this sense, we can assume that the historical constructions of Blackness in Mexico the exclusion of Afro heritage in the "official" history, the representations of Blackness in the Golden Age movies - have had an impact on the way the director views AfroMexicans. His understanding of Blackness in Mexico is based on an exoticization of dark skin tones. Fatimah Tobing Rony touches on how this exoticization works in ethnographic film: 
The people depicted in an "ethnographic film" are meant to be seen as exotic, as people who until only recently were categorized by science as Savage or Primitive, of an earlier evolutionary stage in the overall history of humankind: people without history, without writing, without civilization, without technology, without archives. (Tobing Rony 6)

While Afro-Mexicans are not explicitly called "savage" in La Negrada, it is through this lens of viewing them as "savage" and "exotic" that the director constructs his film. La Negrada clings to the narrative that Mexicans of African descent do not have their own history. Even in its promotional materials, the film treats Blackness in Mexico as an exotic spectacle. "There are Mexicans that nobody sees" is a key phrase that we see both in the trailer and the movie poster.

The film tells the story of Neri, a queridato who has a wife, Juana, and a querida, Magdalena. In the film, Neri is seen going back and forth between his lives with the two women, assisting with Magdalena's restaurant business and tending to the health of Juana, who is terminally ill. This causes Magdalena to be left wondering what will happen with her relationship with Neri once his wife dies. Between these plotlines, we see shots of common places and activities in La Costa Chica - women making and selling fish in the open air, people traveling in the transportation terminal of Pinotepa Nacional, the local beach and laguna in Corraleros. Before every chapter, an older man recites a verse, typical for the region, to advance the overall narrative of the film. We see this type of verse reciting in two other scenes: one in which Magdalena's mother reminds her of a verse that was recited to her as a child, and another scene in which a group of women each recite a verse at a table in Magdalena's and the other mother's restaurant. These scenes give homage to the history of oral tradition in Afro-Mexican communities. Corridos about love, violent deeds, the coastal landscape and other themes have traditionally accompanied the Artesa and Chilena dances of the regions. In turn, "the corrido became an expressive mechanism for narrating the history of the Afro-Mexican residents of the Costa Chica" (González 26).

These particularities of La Costa Chica are meant to give ethnographic glimpses to the viewer, images that show how life is in the region. I can see how these mesmerizing shots can be nostalgic for someone who is from or has been to La Costa Chica, but they also attempt to fit several different social and cultural aspects of La Costa Chica into one single movie. This film's attempt to capture the entirety of La Costa Chica leaves little room for a more-developed story arc and characters. As a result, the narrative in La Negrada falls somewhere between wanting to be a romantic drama and an ethnographic portrait of La Costa Chica. The Black characters in the film are stripped of their own agency and remain on a superficial level of an ethnographic study. We see this from the production, to the development of the plot and characters, to the attempts of visualizing the Afro-Mexican struggle.

As mentioned before, La Negrada was filmed with an entire cast of non-professional actors, all local of La Costa Chica. But the participation from the community stops there. This differs from other examples of documentaries in which the director is not from the community they document. In filming French West Africa, French film director Jean Rouch engaged community members in the cinematography, script writing and other production duties, which Fatimah Tobing Rony describes as "an effort to get beyond scientific voyeurism" (8). By contrast, La Negrada was not made with behind-the-scenes collaboration with the community that it represented. The director mentions in an interview with $\mathrm{El}$ Oriente that he did not know a single soul when arriving to La Costa Chica. Through contacting organizations, he was able to know more about the region and host a casting for local community members, but the actors of the film played little role in the production and narrative side of the film. A more collaborative approach would have allowed in some ways for the community to tell its own story, giving more agency back to the Afro-Mexican population.

A collaborative approach would also have possibly allowed for a more nuanced interpretation of el queridato. The queridato is an arrangement in La Costa Chica that involves domestic relationships outside of the traditional institution of marriage. Gabriel Medina Carrasco suggests that the queridato may have come from a dissidance of racialized populations to seek relationships outside of the ones imposed by the Catholic church during the colonial era: "Sería posible suponer que las comunidades de la Costa Chica poseen arreglos en el plano de la vida sexual y del matrimonio" (155).

In La Negrada, as mentioned before, Neri is the queridato and Juana and Magdalena are his wife and querida, respectively. The women are aware of each other and their arrangement seems to be generally accepted. In El Oriente, the director describes the queridato as "algo que sucede en todo país de manera velada, solo que en la costa es de manera abierta" (Pérez Solano). Here, he compares the queridato to Western standards of matrimony. In his eyes, the queridato is just an open form of adultery, rather than a socially recognized institution. In the film, the querdato is constructed from the man's experience. The women's lives revolve around their relationship with this man, which is implied by their unity through the tono. El tono is a traditional concept in Afro-Mexico that involves a spiritual relationship between humans and animals. When an individual human is born, they are taken to a hill and left there for an animal to greet them. Once an animal arrives and interacts with the child, that animal is designated the child's tono. From then on, the human and the animal share a common destiny. Your tono is your animal "alter ego," representative of your physical and spiritual resistance (Lupo 17). "El tono/tonal, 
which, in conjunction with the body and soul, is believed to be a fundamental part of the existence of each human being" (Weltman-Cisneros 143). The human-tono relationship is one that reminds us that humans and animals must exist in mutuality with nature in order for us all to survive (Weltman-Cisneros 144).

It is said that when a person's tono dies, they pass away along with it. La Negrada plays with this, as Magdalena wonders what will happen to her status as querida when Juana passes away. When Magdalena was born, her family took her to the mountain and waited for her tono to arrive. Instead, a young Juana greeted Magdalena. This encounter confirms that the women share a common destiny. It is not clear that a specific animal is their tono - it is implied that their common destiny is Neri. While the idea of inserting this aspect of Afro-Mexican spiritually in the film seems like a good concept, the execution is weak, as it uses the spirituality as a narrative device in the arc of this romantic drama.

Although the arrangement of the queridato involves control and regulation over a woman's sexuality, Gabriel Medina Carrasco provides some understanding of the queridato from the experience of la querida:

"El 'queridato' provee a la "querida" un mayor estatus social debido a su autonomía económica, en cambio la esposa depende de la economía de su pareja. En el "queridato"...la mujer no está expuesta al escarnio público sobre su virginidad, ni debe someter su cuerpo al humillante ritual de comprobación y reconocimiento social de tal condición" (156).

This type of autonomy by part of Magdalena is not explicitly expressed in the film, though it could be interpreted as such by some viewers. After Juana passes away toward the end of the film, Magdalena asks Neri if he is going to live with her now. The viewer is left to assume that Magdalena desires that prestige status of marriage.

The film also interprets the queridato with the assumption that this arrangement of privileged masculinity is justified by the community, without question from its members. Indeed, the queridato is a social institution, but it does not come without critique. In my third trip to La Costa Chica, at a forum for issues of Afro-Mexican women in Collantes, the queridato arrangement was discussed by women from the community. Afro-Mexican activist Julia Acevedo stated, "Tenemos que cuestionar la existencia del querido... si tuviéramos queridata, tal vez sería otra historia." The various forms in which Afro-Mexicans construct and reflect on their own communities - the forms in which they express their self-determination - is absent in the film.

Additionally, we see some instances where whiteness seems to be a desired trait in the characters, for example when Sara dyes her hair blonde or when her sister steals her blonde highlights. In other instances, characters distance themselves from Blackness. In a scene in front of Magdalena's restaurant, two African-Americans are seen ordering food (we assume they are American because they order in English), one of Magdalena's sons makes a joke about them, saying "ese parece chocolate se puede derretir por el calor". The scene seems irrelevant to the rest of the plotline, and leads the viewer to interpret that Afro-Mexicans do not want to be Black.

The film also employs codified stereotypes about Black Mexicans. Magdalena's daughter seems uninterested in anything that is not dancing and flirting, to a point where people make fun of her for being "just like her dad," reinforcing the stereotype of "la Negra caliente." Neri is painted as "el Negro flojo" throughout the film, half-completing tasks and scolded by the women in his life for doing so. Certainly, it is human to be flirtatious or to feel lazy, but the film does not develop these traits of the characters in the context of nuance. Rather, these traits are developed from what the producers understand as characteristics of Blackness.

La Negrada does attempt to give a glimpse of the treatment and discrimination towards Afro-Mexicans, but without giving much agency back to the Afro-Mexican population. White Mexican tourists are shown taking pictures of the characters, without much question or resistance from the characters themselves. This lack of agency is especially evidenced in the scene where Sara is racially profiled and asked to sing the national anthem by a migration officer because she does not "look" Mexican, which is a real and common occurrence for darker-skinned Mexicans. She obliges, singing the anthem word for word. The agency she has to challenge the officer is taken from her and she gives in to the powers of the State. The scene is a moment that demonstrates the film's desire to absorb Blackness into the State-sponsored idea of mestizaje. Black Mexicans are Mexicans, above all, and singing the national anthem is the ultimate expression of their mexicanidad. But this type of submission to patronage is not characteristic of all AfroMexicans. In the short documentary, Así Somos: Afro Identities on the Coast by Andy Amaya, an Afro-Mexican man recounts a similar story of being stopped by migration and asked to sign the national anthem. However, unlike Sara in La Negrada, this man challenges the officer in a sarcastic remark, asking him “¿Cómo lo quieres? ¿Platicado? ¿Cantado?” This is the type of gesture that gives agency back to Black people, and the director's decision to share this testimony in the film is powerful.

The struggle for visibility within the Afro-Mexican community is addressed once in the film, when a young girl is shown handing out flyers for a forum that discusses the fight for Afro-Mexican recognition in the national constitution. Afro-Mexicans have been campaigning to be recognized in the constitution for decades, and this is something that could have been developed more throughout the film. Because of this underdevelopment, the flyer scene feels a bit 
forced, done by the director from a place that feels more like obligation rather than motive. The fight for visibility takes many forms in the Afro-Mexican population. With more development on this front, the film could have integrated these diverse forms of lucha as a natural organic part of the film, further capturing the nuances of the Afro-Mexican experience.

\section{Conclusion}

Mexico's construction of mestizaje as a national identity has impacted the way Blackness is represented in the structures of visuality. Coloniality has operated to represent Blackness in some of the most common spaces in Mexico, such as comics, music and cinema. These references in popular culture have aided in rendering Blackness in Mexico as something invisible yet problematic. In the Golden Age of Mexican cinema, films represented codings of Blackness through blackface, the "tragic mulatto" and dialogues that took away from the agency of the Black characters. La Negrada, on the other hand, does not use blackface or the tragic mulatto to construct a narrative on Blackness in Mexico. However, the coloniality in La Negrada exists in more subtle ways, primarily in its role as an ethnographic film. In analyzing the film and looking at the ways it interprets different aspects of afromexicanidad, we can propose strategies in film that aim for emancipation from the colonial gaze.

\section{NOTES}

1. The casta "Salta pa' tras," translated to mean "a step back" was used to categorize people with Black and Indigenous blood.

2. The Golden Age, or La Época de Oro de cine, is commonly said to have spanned from the mid 1930 s to the early 1960 s.
3. The term Sambo actually comes from zambo, a Spanish casta that described people with mixed Black and Indigenous heritage)

\section{WORKS CITED}

Acevedo, Juliana. Foro Afromexicano: En Conmemoración del Día Internacional de la Mujer Afrolatinoamericana, Afrocaribeña y de la Diáspora, 28 July 2018, Santiago Collantes, Oaxaca, México. Presentation.

Aguirre Beltrán, Gonzalo. La población negra de México: estudio etnohistórico. Fondo de Cultura Económica, 1972.

Amaya, Andy. Así Somos: Afro Identities on the Coast. YouTube, uploaded by Lepa Productions, 11 December 2014, https://www.youtube.com/watch?v=uEktkb_Cts4.

Angelitos Negros. Directed by Joselito Rodriguez, performances by Emilia Guiú, Pedro Infante and Rita Montaner, Producciones Rodríguez, 1948.

Arce, B. Christine. Mexico's Nobodies : the Cultural Legacy of the Soldadera and Afro-Mexican Women. SUNY Press, 2017.

Barriendos, Joaquín. "La colonialidad del ver. Hacia un nuevo diálogo visual interepistémico." Nómadas, no. 35, Universidad Central de Colombia, 2011, pp. 13-30
Castro-Gómez, Santiago. "Cuerpos racializados: para una genealogía de la colonialidad del poder en Colombia.” $\mathrm{Al}$ otro lado del cuerpo: estudios biopolíticos en América Latina, edited by Hilderman Cardona and Zandra Pedraza, Universidad de los Andes, 2014, pp. 79-95.

Dios Sabrá Juzgarnos. Directed by Fernando Cortés, performances by Rosa Arenas, Alfredo Wally Barrón, and Juan José Laboriel, Producciones Espada S. de R.L., 1961.

Cuevas, Marco Polo Hernández, and Richard L. Jackson. African Mexicans and the discourse on modern nation. University Press of America, 2004.

Cuevas, Marco Polo Hernández. “Memín Pinguín’: uno de los cómics mexicanos más populares como instrumento para codificar al negro." Afro-Hispanic Review, vol. 22, no. 1, 2003, pp. 52-59.

Gonzalez, Anita. Afro-Mexico Dancing Between Myth and Reality. University of Texas Press, 2010.

La Negrada. Directed by Jorge Pérez Solano, performances by Felipe Neri Corcuera Acevedo, Magdalena Soriano, and Sara Gallardo, Tirisia Cine, 2018. 
Lupo, Alessandro, "Nahualismo y tonalismo." Arqueología Mexicana, vol. 6, no. 35, 1999, pp. 18-23.

Medina Carrasco, Gabriel. Afromexicanos de la Costa Chica: Colonialidad y Sexualidad en la "Zona del No Ser." 2017. El Colegio de México, PhD Dissertation.

Mignolo, Walter, and Pedro Pablo Gómez. Estéticas decoloniales. Bogotá, Universidad Distrital Francisco José de CaldasASAB, 2012.

Monsiváis, Carlos. "Memín Pinguín” El Universal.mx. 10 July 2005, http://archivo.eluniversal.com.mx/editoriales/29632.html. Accessed 4 Jan 2019.

Moore, Robin. "The Teatro Bufo: Cuban Blackface Theater of the Nineteenth Century." Soundscapes from the Americas: Ethnomusicological Essays on the Power, Poetics, and Ontology of Performance, edited by Donna A. Buchanan, Routledge, 2014. pp. 25-42.

Negro es Mi Color. Directed by Tito Davison, performances by Marga López and Rita Montaner, Filmex, 1951.

Ortiz, Roberto. "Performing Blackness in Mexican Cinema: Eusebia Cosme, Rita Montaner and Juan José Laboriel." Mediático. 11 March 2018, http://reframe. sussex.ac.uk/mediatico/2018/03/09/performing-blackness-in-mexican-cinema-eusebia-cosme-rita-montaner-and-juan-jose-laboriel/. Accessed 24 May 2018.

Pérez Solano, Jorge. "La Negrada, Filme de Ficción que Aborda el Tema de la Tercera Raíz en México." Interview with Sergio Raúl Lopez. La Jornada,10 Aug. 2018.

--“EL Queridato, ¿sabes que La Negrada trata sobre esta práctica?” Interview with El Oriente, 10 Aug. 2018.

Rony, Fatimah T. The Third Eye: Race, Cinema, and Ethnographic Spectacle. Duke University Press, 1996.

Roper, Danielle, et al. Inca Drag Queens and Hemispheric Blackface: Contemporary Blackface and Drag Performance from the Andes to Jamaica. 2015. New York University, PhD Dissertation. ProQuest, http://search.proquest.com/ docview/1758252306/.

Quijano, Aníbal. “Colonialidad y modernidad/racionalidad.” Perú indígena, vol. 13, no. 29, 1992, pp. 11-20.

Vasconcelos, José. La raza cósmica: misión de la raza iberoamericana. Madrid, Aguilar, 1966.

Weltman-Cisneros, Talia, et al. (Re)mapping the Borderlands of Blackness: Afro-Mexican Consciousness and the Politics of Culture. 2013. Duke University, PhD Dissertation. ProQuest, http://search.proquest.com/ docview/1433829504. 